\title{
The Alpha2-Adrenoceptor Antagonist Dexefaroxan Enhances Hippocampal Neurogenesis by Increasing the Survival and Differentiation of New Granule Cells
}

\author{
Pamela Rizk ${ }^{1,2,3}$, Julio Salazar ${ }^{1,2,3}$, Rita Raisman-Vozari ${ }^{1,2,3}$, Marc Marien ${ }^{4}$, Merle Ruberg ${ }^{1,2,3}$, \\ Francis Colpaert ${ }^{4}$ and Thomas Debeir*, ${ }^{*, 2,3}$ \\ 'INSERM U679, Neurology and Experimental Therapeutics, Paris, France; ${ }^{2}$ Hôpital de la Salpêtrière, Paris, France; ${ }^{3}$ Faculté de Médecine, \\ Université Pierre et Marie Curie, Paris, France; ${ }^{4}$ Centre de Recherche Pierre Fabre, Castres, France
}

\begin{abstract}
The generation of new neurons in the hippocampus is a dynamic process regulated by environmental, endocrine, and pharmacological factors. Since enhancement of hippocampal neurogenesis has been associated with learning and memory, and the locus coeruleusnoradrenergic system has been shown to modulate these cognitive functions, we hypothesized that activation of noradrenergic neurotransmission might enhance neurogenesis in the adult hippocampus. To test this hypothesis in vivo, we induced the release of noradrenaline in the hippocampus by blocking presynaptic inhibitory autoreceptors with the selective alpha2-adrenoceptor antagonist dexefaroxan. Confocal microscopy showed that noradrenergic afferents make contact with proliferating and differentiating cells, suggesting a direct noradrenergic influence on neurogenesis. Chronic systemic treatment of rats with dexefaroxan did not affect cell proliferation per se in the dentate gyrus (as monitored by bromodeoxyuridine-labeling), but promoted the long-term survival of newborn neurons by reducing apoptosis. Dexefaroxan treatment also enhanced the number and complexity of the dendritic arborizations of polysialated neural cell adhesion molecule-positive neurons. The trophic effects of dexefaroxan on newborn cells might involve an increase in brain-derived neurotrophic factor, which was upregulated in afferent noradrenergic fiber projection areas and in neurons in the granule cell layer. By promoting the survival of new endogenously formed neurons, dexefaroxan treatment represents a potential therapeutic strategy for maintaining adult neurogenesis in neurodegenerative conditions, such as Alzheimer's disease, that affect the hippocampus.

Neuropsychopharmacology (2006) 3 I, I |46-I 157. doi:I0. I038/sj.npp. I 300954; published online I6 November 2005
\end{abstract}

Keywords: BDNF; noradrenaline; plasticity; BrdU; cell death; progenitor; neural stem cell

\section{INTRODUCTION}

Adult neurogenesis is a dynamic process that occurs in the brains of several different species, including man (Eriksson et al, 1998). The two best-established regions in which adult neurogenesis is observed are the subventricular zone and the dentate gyrus (DG) of the hippocampus. In the subventricular zone, proliferating progenitor cells differentiate into neurons that migrate to the olfactory bulb (Doetsch and Alvarez-Buylla, 1996; Lois and Alvarez-Buylla, 1994). In the hippocampus, proliferating progenitors in the subgranular zone (sgz) migrate to the granule cell layer (gcl)

\footnotetext{
*Correspondence: Dr T Debeir, INSERM U679, Neurology and Experimental Therapeutics, Hôpital de la Salpêtrière, 47 boulevard de l'Hôpital, Paris 750 13, France, Tel: + 33 | 42 I6 22 17, Fax: + 33 | 44 2436 58, E-mail: tdebein@ccr.jussieu.fr

Received 15 February 2005; revised 31 August 2005; accepted 22 September 2005

Online publication: 6 October 2005 at http://www.acnp.org/citations/ Npp I00605050 104/default.pdf
}

where they form new neurons that innervate the $\mathrm{CA} 3$ region (Cameron et al, 1993).

Neurogenesis in the hippocampus is of particular interest because of the role this structure plays in learning and memory. It is known that hippocampal neurogenesis is sensitive to environmental, endocrine, and pharmacological factors. It is increased by exposure to an enriched environment, exercise, antidepressants, and hippocampusdependent learning (Duman et al, 2001a,b; Malberg et al, 2000 ) and is decreased with aging, and by environmental or psychosocial stress and glucocorticoids (Cameron and McKay, 1999; Gould et al, 1999a; Kuhn et al, 1996). However, the endogenous factors (neurotransmitters or neurotrophins) that regulate neurogenesis in the adult hippocampus must be better identified.

The hippocampus has an abundant noradrenergic innervation (Loy et al, 1980) that promotes both short- and long-term enhancement of sensory-evoked responses in the DG, consistent with a role in hippocampal learning and memory (Harley, 1991). Recent studies have reported that 
altering noradrenaline levels can change the rate of progenitor proliferation in the hippocampus. Noradrenergic depletion with the selective noradrenergic neurotoxin $\mathrm{N}$-(2chloroethyl)- $N$-ethyl-2-bromo benzylamine hydrochloride (DSP-4) decreased the number of proliferating cells in the DG of the adult rat (Kulkarni et al, 2002). Conversely, increasing synaptic levels of noradrenaline with antidepressants, including selective noradrenaline reuptake inhibitors, enhanced neurogenesis (Malberg et al, 2000). Furthermore, activation of the noradrenergic system by blockade of presynaptic inhibitory autoreceptors with an alpha2-adrenoceptor antagonist has been reported to increase adult neurogenesis in the olfactory bulb, by preventing the loss of newly formed neurons (Bauer et al, 2003).

We therefore hypothesized that antagonism of alpha2adrenoceptors would enhance neurogenesis in the DG as it does in the olfactory bulb, given that alpha2-adrenoceptor blockade increases noradrenaline synthesis and release in forebrain target areas including the hippocampus (van Veldhuizen et al, 1994). To test this hypothesis, we first studied the rate of proliferation and cell death in the DG of the dorsal hippocampus following acute and chronic treatment with the selective alpha2-adrenoceptor antagonist dexefaroxan. We then determined the effects of dexefaroxan treatment on differentiation and on morphological plasticity in this structure and investigated whether this treatment could modify the endogenous levels of brainderived neurotrophic factor (BDNF), a target-derived survival factor for newborn neurons in the DG.

\section{MATERIALS AND METHODS}

\section{Animals}

Animals were housed, handled, and cared for in accordance with the Guide for the Care and Use of Laboratory Animals (NCR, 1996) and the European Union Council Directive $86 / 609 / \mathrm{EEC}$, and the experimental protocols were carried out in compliance with institutional ethical committee guidelines for animal research. All efforts were made to minimize the number of animals used and their suffering.

Male Sprague-Dawley rats (IOPS Han, Centre d'Elevage René Janvier, Le Genest St Ile, France), weighing 250-300 g at the beginning of the experiments, were housed two per cage at $22^{\circ} \mathrm{C}$ under a $12 \mathrm{~h}$ light:dark cycle (lights on at 0700 hours AM) with free access to food and water. Five rats were used for each experimental condition.

Acute treatment with dexefaroxan consisted of four intraperitoneal (i.p.) injections of vehicle $(3 \mathrm{ml} / \mathrm{kg})$ or dexefaroxan $(0.63 \mathrm{mg} / \mathrm{kg})$ at 4 -hr intervals. For chronic treatment, a single i.p. injection of vehicle $(3 \mathrm{ml} / \mathrm{kg})$ or dexefaroxan $(0.63 \mathrm{mg} / \mathrm{kg})$ was administered just before subcutaneous implantation of ALZET ${ }^{\circledR}$ osmotic minipumps (model 2ML4) under equithesin anesthesia $(2.5 \mathrm{ml} / \mathrm{kg}$ i.p). The pumps delivered vehicle (distilled water) or dexefaroxan $(0.63 \mathrm{mg} / \mathrm{rat} /$ day $)$ over a 28 -day period. To verify that dexefaroxan was released by the minipumps for 28 days, we monitored the inhibition of hypothermia induced by alpha2-adrenoceptor agonist (data not shown). For longterm treatment (70 days), the pumps were changed every 28 days.
At the end of the experiments, the rats were anesthetized with equithesin $(2.5 \mathrm{ml} / \mathrm{kg}$ i.p.) and perfused transcardially with saline buffer containing $0.1 \% \mathrm{NaNO}_{3}$ and heparin ( $5 \mathrm{U} / \mathrm{ml})$, followed by a 20 -min perfusion with $4 \%$ paraformaldehyde ( $\mathrm{pH}$ 7.4). Brains were then removed, postfixed in the same fixative for $2 \mathrm{~h}$ at $4{ }^{\circ} \mathrm{C}$, and cryoprotected in $15 \%$ sucrose in distilled $\mathrm{H}_{2} \mathrm{O}$ at $4{ }^{\circ} \mathrm{C}$ for 2 days. The brains were cut into $25 \mu \mathrm{m}$ coronal sections through their entire length with a sledge freezing microtome at $-20^{\circ} \mathrm{C}$.

\section{Determination of Noradrenaline Concentrations by Microdialysis and HPLC}

Intracerebral microdialysis was used to assess the effect of dexefaroxan on hippocampal noradrenaline release in vivo. Surgery was performed as described previously (Tellez et al, 1999) with minor modifications. Rats were anesthetized with a halothane/oxygen mixture and were implanted under stereotaxic control with a microdialysis probe (CMA/12, $3 \mathrm{~mm}$ membrane length; CMA/Microdialysis AB, Stockholm, Sweden) terminating in the hippocampus $(5.4 \mathrm{~mm}$ posterior to bregma, $4.9 \mathrm{~mm}$ lateral to the midline at bregma, $6.5 \mathrm{~mm}$ ventral from dura). Probes were anchored to the skull with stainless-steel screws and dental acrylate. Immediately after surgery, rats were placed in bowl-shaped Plexiglas cages with free access to food and water. The dialysis probe was immediately connected to a microliter syringe pump and perfused with Ringer's solution $(147 \mathrm{mM}$ $\mathrm{NaCl}, 4 \mathrm{mM} \mathrm{KCl}, 1.3 \mathrm{mM} \mathrm{CaCl}_{2}$ ) at a flow rate of $0.2-0.4 \mu \mathrm{l} /$ min during an overnight recovery period. The following morning, the infusion syringes were refilled with fresh filtered and degassed Ringer's solution, and the pump infusion rate was increased to $2.0 \mu \mathrm{l} / \mathrm{min}$. After a $2.5 \mathrm{~h}$ equilibration period, three 20-min dialysate samples were collected in glass microtubes containing $10 \mu \mathrm{l}$ of $1 \mathrm{mM}$ $\mathrm{Na}_{2}$ EDTA in $0.05 \mathrm{M} \mathrm{HCl}$, for baseline measurements of endogenous noradrenaline. Animals then received an i.p. injection of vehicle (saline) or dexefaroxan $(0.63 \mathrm{mg} / \mathrm{kg})$, and dialysate samples were collected continuously for $5 \mathrm{~h}$. At the end of the experiment, the rats were decapitated and the brains removed and fixed in $4 \%$ formalin solution. Coronal sections $(500 \mu \mathrm{m}$ thick $)$ of fixed brain were prepared using a Vibroslice oscillating microtome (Campden Instruments, London, UK), and probe placement was assessed by visual inspection of the probe tract in the tissue.

Noradrenaline in the dialysates was derivatized and analyzed by HPLC with fluorescence detection as described (Yoshitake et al, 2003). This method is based on precolumn derivatization of noradrenaline with benzylamine in the presence of potassium hexacyanoferrate(III), resulting in a highly fluorescent and stable benzoxazole derivative. Derivatized samples were loaded into a refrigerated HPLC system (Waters 2690 Alliance Separation Module) for automated injection and analysis. Chromatographic conditions consisted of a $\mathrm{C}_{18}$ reverse-phase column (Waters Symmetry Shield, $2.1 \times 150 \mathrm{~mm}, 5 \mu \mathrm{m}$ particle size) maintained at $30^{\circ} \mathrm{C}$, and a mobile phase (flow rate $0.4 \mathrm{ml} / \mathrm{min}$ ) composed of $15 \mathrm{mM}$ sodium acetate, $4 \mathrm{mM}$ octane sulfonic acid, and acetonitrile (25\% (vol/vol)), final $\mathrm{pH} 4.5$. Fluorescent derivatives were detected with a Waters Model 474 scanning fluorescence detector $\left(\lambda_{\mathrm{ex}}=345 \mathrm{~nm}\right.$, $\left.\lambda_{\mathrm{em}}=480 \mathrm{~nm}\right)$. Quantification of the chromatographic peak 
of noradrenaline was based on the comparison with calibration curves derived from authentic standards of noradrenaline $(0.1-10 \mathrm{pg} / \mu \mathrm{l})$ prepared in Ringer's solution and carried through the derivatization procedure. The level of noradrenaline in the dialysates was expressed as a percentage of the average amount of noradrenaline in the three baseline samples preceding drug or vehicle injection. For the comparison of drug and vehicle treatments between different subjects at corresponding time points, KruskalWallis ANOVA followed by Mann-Whitney U-test was used.

\section{Analysis of Cell Proliferation with Bromodeoxyuridine (BrdU)}

$\mathrm{BrdU}(50 \mathrm{mg} / \mathrm{kg}, 15 \mathrm{mg} / \mathrm{ml}$ in $0.9 \% \mathrm{NaCl}$ containing $0.007 \mathrm{~N}$ $\mathrm{NaOH}$; Sigma, St Louis, MO) that is incorporated into cellular DNA during the $S$ phase of the cell cycle was injected i.p. either once or on 7 consecutive days preceding treatment with dexefaroxan (see Results for experimental designs). BrdU incorporation was determined by immunohistochemistry with an anti-BrdU antibody (see below).

\section{Immunohistochemistry}

Free-floating $25 \mu \mathrm{m}$ sections of fixed brains from the experimental groups were processed in parallel. Immunohistochemistry was performed by standard procedures. Briefly, sections were pretreated with $0.3 \% \mathrm{H}_{2} \mathrm{O}_{2}$ in $0.1 \mathrm{M}$ PBS and incubated in blocking solution (5\% normal horse serum and $0.2 \%$ Triton X-100 in PBS), and then with primary antibodies for $48 \mathrm{~h}$ at $4{ }^{\circ} \mathrm{C}$ in PBS. Antibody binding was visualized with appropriate secondary antibodies (incubation, $2 \mathrm{~h}$ at room temperature), either coupled directly with fluorescent markers or biotinylated for revelation with horseradish peroxidase ( $A B C$ Vectastain kit, Vector laboratories, Burlingame, CA) and diaminobenzedine (DAB, $0.5 \mathrm{mg} / \mathrm{mL}$; Sigma) as chromogen. For BrdU labeling, sections were first denatured in $2 \mathrm{M} \mathrm{HCl}$ for $30 \mathrm{~min}$ at $37^{\circ} \mathrm{C}$ and then neutralized in $0.1 \mathrm{M}$ borate buffer, $\mathrm{pH} 8.5$, for $10 \mathrm{~min}$. Multifluorescent labeling was carried out sequentially. To label nuclei, sections were counterstained with Hoechst 33342. Labeled sections were mounted on glass slides with Mowiol medium (Calbiochem, San Diego, CA). Fluorescent images of mounted sections were acquired with an epifluorescent microscope (Axioplan 2, Zeiss, Germany) equipped with FluoUp image analysis system software (Explora Nova, La Rochelle, France).

The primary antibodies used were: rat anti-BrdU (mAb, 1:200; ImmunologicalsDirect, Oxfordshire, UK); mouse anti-polysialated neural cell adhesion molecular (PSANCAM) (monoclonal IgM, 1 : 1000; gift of G Rougon, Centre National de la Recherche Scientifique, Marseille, France); mouse anti-NeuN (1:200; Chemicon, Temecula, CA); mouse anti-GFAP ( $1: 1000$; Sigma); mouse anti-proliferating cell nuclear antigen (PCNA) (1:100; DAKO, Denmark); rabbit anti-BDNF (1:1000; gift of Dr Q Yan, Amgen, Thousand Oaks, CA); rabbit anti-noradrenaline transporter (NET) (1:5000; gift of Dr RD Blakely, Vanderbilt University, Nashville, TN); goat anti-doublecortin (1:200; Santa Cruz Biotechnology, Santa Cruz, CA), and guinea-pig anti-alpha2c-adrenoceptor (1:300; Neuromics, Bloomington, $\mathrm{MN}$ ).

The secondary antibodies used were biotinylated anti-rat (1:250; Vector Laboratories) or biotinylated anti-mouse IgM (1:200; Zymed, South San Francisco, CA), Cy3conjugated anti-rat, Cy3-conjugated anti-rabbit, FITC-conjugated anti-mouse IgM, FITC-conjugated anti-mouse (1:400, $1: 400,1: 150,1: 100$, respectively; Jackson Laboratories, West Grove, PA), and Cy3-conjugated anti-goat (1:400; Chemicon).

\section{Terminal Deoxynucleotidyl Transferase (TdT)-Mediated UTP Nick-End Labeling (TUNEL)}

The TUNEL assay was performed on free-floating sections using the Apoptag In Situ cell death detection kit (Intergene, Purchase, NY) as described previously (Tonchev et al, 2003). Briefly, the sections were washed in TBS containing $0.15 \%$ Triton X-100, dehydrated in an ascending ethanol/distilled water series (30-70-95\%, $5 \mathrm{~min}$ each), incubated in $100 \%$ ethanol $(15 \mathrm{~min})$, and gradually rehydrated. The sections were then placed in the equilibration buffer, followed by incubation in the TdT/reaction buffer mixture (15/85, ApopTag kit) at $37^{\circ} \mathrm{C}$ for $2 \mathrm{~h}$. The reaction was visualized by overnight incubation at $4^{\circ} \mathrm{C}$ with sheep anti-digoxigenin-fluorescein antibody in blocking solution (62/68, ApopTag kit). The sections were counterstained with Hoechst 33342 and then mounted on glass slides with Mowiol medium, and visualized as above.

\section{Stereological Cell Counts}

BrdU-labeled nuclei and PSA-NCAM cells were counted by the optical dissector method using a microscope (Axioplan 2) equipped with a $\times 100$ objective (numerical aperture 1.4), a video camera (Retiga, Qimaging, BC, Canada), and an image analysis system (Mercator, ExploraNova, La Rochelle, France) dedicated to stereology (Howard et al, 1985). Series of regularly spaced sections at $300 \mu \mathrm{m}$ intervals (every 12 sections, for a total of six sections) covering the dorsal hippocampus were sampled, starting where the DG blades become fully established (approximately $2.6 \mathrm{~mm}$ posterior to Bregma). The analysis was performed bilaterally and sampling ended where the hippocampus contained both a dorsal and ventral component, at approximately $4.3 \mathrm{~mm}$ posterior to Bregma (Paxinos and Watson, 1986). The gcl always included the sgz, defined here as a two-cell body wide border between the $\mathrm{gcl}$ and hilus. The boundaries of the structures in the coronal plane were determined microscopically ( $\times 4$ objective). The average section was initially $25 \mu \mathrm{m}$ thick (with an estimated average shrinkage of $37 \%$ taken into account in the final results). The top and bottom $2.5 \mu \mathrm{m}$ were excluded from the analysis. The average number of profiles counted $\left(Q_{-}\right)$per region per animal was 102 for BrdU-labeled nuclei and 134 for PSA-NCAM. The density of the cells $(\mathrm{Nv})$ was calculated with the formula $\mathrm{Nv}=\sum Q-/ a \times h$, where $a$ is the total area of section examined for the given region and $h=300 \mu \mathrm{m}$. The total number of cells in the DG and in the hilus was estimated by multiplying the volume of the region by the corresponding cellular density. 
For colocalization studies with NeuN or GFAP, BrdUlabeled cells were first counted using a fluorescent microscope. Confocal microscopy (Leica DM IRBE, Germany) was then used to determine the percentage of colabeled cells in the dorsal hippocampus. For each animal, 15 random fields containing BrdU-labeled cells were examined. Differences between mean values for each treatment group were analyzed by Kruskal-Wallis ANOVA followed by Mann-Whitney $U$-test.

\section{Quantification of BDNF Immunostaining}

For quantitative analysis of BDNF staining, sections from control and experimental animals were processed simultaneously. The density of BDNF immunostaining was assessed using the same computerized image analysis system equipped with software for optical density measurements. BDNF staining was analyzed in five anatomical regions of the hippocampus (hilus, gcl, CA1, CA3 pyramidal cell body layer, and CA3 stratum radiatum), corresponding to the same levels used for the BrdU and PSA-NCAM cell counting. Optical density was determined as gray levels and expressed in arbitrary units. Blank values were measured where no BDNF immunostaining was observed. Differences between mean values for each treatment group were analyzed by Kruskal-Wallis ANOVA followed by Mann-Whitney U-test.

\section{RESULTS}

\section{Dexefaroxan Increases Noradrenaline Release in the Hippocampus In Vivo}

We first confirmed that the alpha2-adrenoceptor antagonist, dexefaroxan, enhanced noradrenaline release in the

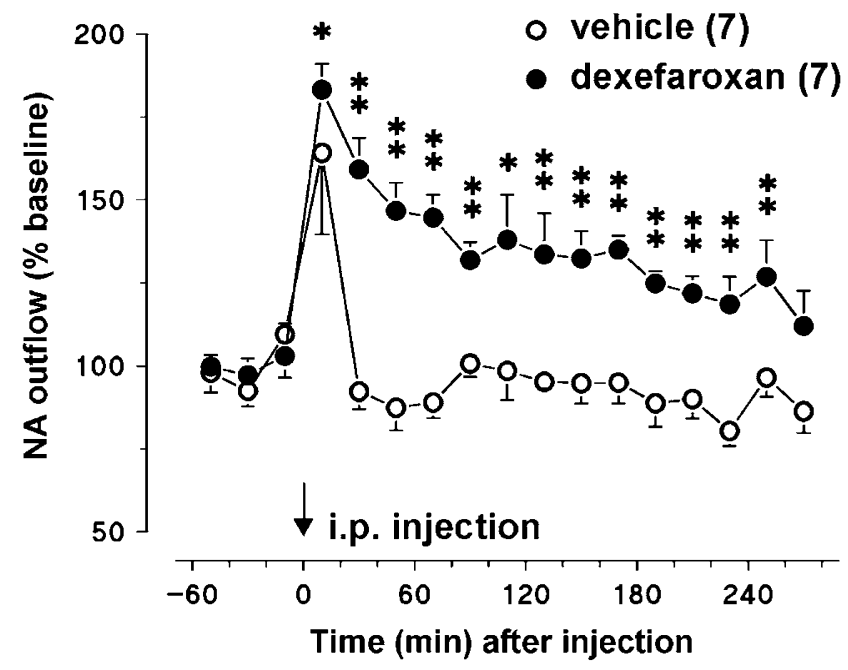

Figure I Effect of a single i.p. injection of saline or dexefaroxan $(0.63 \mathrm{mg} /$ $\mathrm{kg}$ ) on the outflow of endogenous noradrenaline (NA) in the ventral hippocampus of conscious freely moving rats measured by microdialysis. Baseline: the average amount of noradenaline in three 20-min dialysis samples collected prior to i.p. injection $(t=0 \mathrm{~min}$ ). Significantly different than corresponding samples from vehicle-injected animals $(* p<0.05$, ** $p<0.0$ I; Kruskal-Wallis ANOVA followed by Mann-Whitney U-test, $n=7$ rats per group). hippocampus by microdialysis in conscious freely moving rats (Figure 1). I.p. injection of the vehicle evoked an immediate $64 \%$ increase in noradrenaline outflow that returned to baseline levels by $20 \mathrm{~min}$ postinjection. Dexefaroxan $(0.63 \mathrm{mg} / \mathrm{kg}$ i.p.) also evoked an immediate increase $(+74 \%)$ in noradrenaline outflow, which remained significantly higher (32-73\%) than in vehicle-treated animals for up to $4 \mathrm{~h}$ (Figure 1). Upregulation of noradrenaline release by dexefaroxan is therefore potentially able to affect target cells in the DG of the hippocampus.

\section{What Cells in the DG Receive Noradrenergic Innervation?}

We next analyzed the noradrenergic innervation of the DG in vehicle-treated rats. Presynaptic alpha2-adrenoceptors were present on fibers innervating the gcl of the dorsal hippocampus (Figure 2a). Noradrenergic fibers identified by immunoreactivity for the NET were found in abundance throughout the dorsal hippocampus, with a high density in the DG (Figure $2 b$ and $c$ ). NET-positive fibers were observed in close proximity to cells positive for PCNA (marker of proliferation) (Figure $2 \mathrm{~d}$ and e) and to cells positive for the membrane-associated polysialated neural cell adhesion molecule (PSA-NCAM) (marker of differentiation) (Figures 2f, g). Confocal microscopy revealed noradrenergic contacts both with PCNA-positive cells (Figure 2e) and with PSANCAM-positive cells (Figure 2g). These observations suggested that both newborn PSA-NCAM-positive granule cells and proliferating PCNA-positive precursors were potentially responsive to noradrenaline release induced by dexefaroxan. This hypothesis was examined in the following experiments.

\section{Dexefaroxan does not Affect the Rate of Cell Proliferation in the Adult DG}

To determine how increased noradrenaline release in the hippocampus affects adrenoreceptive target cells, we first examined the effects of both acute and chronic dexefaroxan administration on the rate of cell proliferation in the DG of the dorsal hippocampus. For the acute treatment, the rats received a single i.p. injection of $\mathrm{BrdU}(50 \mathrm{mg} / \mathrm{kg})$ followed immediately by four i.p. injections of vehicle $(3 \mathrm{ml} / \mathrm{kg})$ or dexefaroxan $(0.63 \mathrm{mg} / \mathrm{kg})$ at $4 \mathrm{~h}$ intervals. Rats were killed $24 \mathrm{~h}$ later, a time period sufficient for all cells that incorporated BrdU during the $S$ phase to complete mitosis. Effects of chronic treatment were examined in rats that received a single i.p. injection of BrdU after subcutaneous administration of dexefaroxan with a minipump for 20 days and were killed $24 \mathrm{~h}$ later. The results are shown in Figure 3. A 21 day survival period was chosen because in that interval around $50 \%$ of new cells will have died (Dayer et al, 2003).

After a $24 \mathrm{~h}$ exposure to both BrdU and dexefaroxan, proliferating cells with BrdU-positive nuclei were observed predominantly in the deeper layers of the gcl (Figure 3a and b). The nuclei were darkly and uniformly stained and varied in shape and the cells frequently appeared in clusters of two or more (Figure $3 \mathrm{~b}$ ). This observation that, at $24 \mathrm{~h}$, BrdUpositive cells were rarely found outside the interface between the gcl and the hilus suggest that incorporation of BrdU occurred during proliferation of progenitor cells 

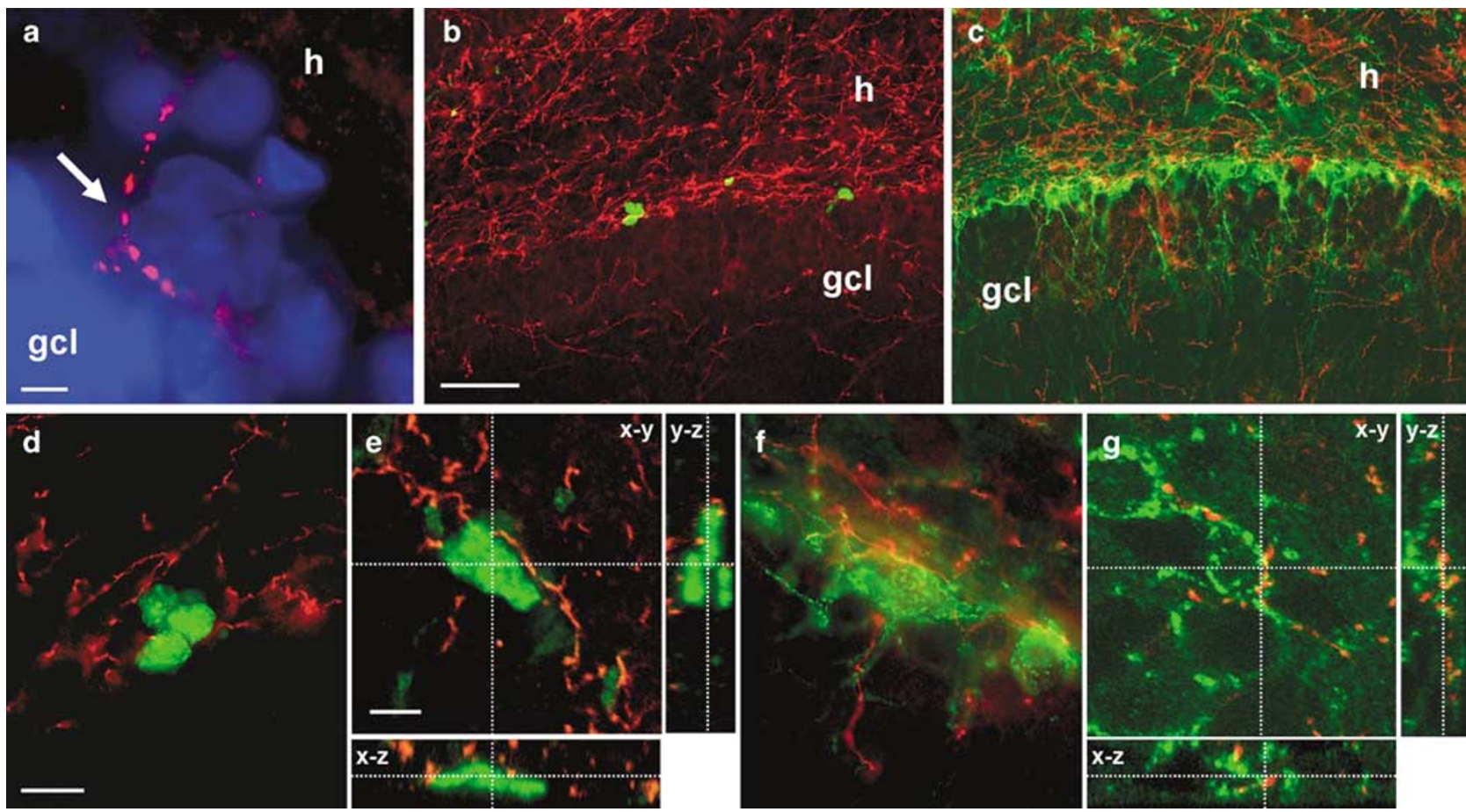

Figure 2 Markers of noradrenergic innervations in the DG. (a) Presynaptic alpha2c-adrenoceptors (red, arrow,) on fibers in the gcl. Hoechst 33342stained nuclei are shown in blue. (b and c) NET-positive fibers (red) in the hilus and gcl contiguous to proliferating PCNA-positive cells (b, green) and PSANCAM-positive cells (c, green). (d-g) NET-positive fibers (red) were also found in proximity to PCNA-positive (d and e, green) and PSA-NCAM-positive ( $f$ and $g$, green) cells in the sgz. Corresponding orthogonal reconstructions of confocal images are shown in $x-y, x-z$, and $y-z$ planes in (e) and (g). Scale bars $=5 \mu \mathrm{m}$ (a, e and g), $50 \mu \mathrm{m}$ (b and c), $10 \mu \mathrm{m}$ (d and f).

rather than as a result of a damaged DNA repair process (Cameron and McKay, 2001). The morphology and distribution of nuclei of Brdu cells were similar in the dexefaroxan- and vehicle-treated control animals (not shown).

The numbers of BrdU-labeled nuclei in both the gcl and the hilus, determined by stereological cell counts, were similar after acute injection $(24 \mathrm{~h})$ or chronic treatment $(21$ days) in both dexefaroxan treated animals and vehicle controls (Figure $3 \mathrm{c}$ and $\mathrm{d}$ ). These results show that neither acute nor long-term dexefaroxan treatment up to 21 days affected the rate of cell division over a $24 \mathrm{~h}$ period in the DG. Dexefaroxan treatment does not therefore affect the rate of cell proliferation (number of cells entering the $S$ phase in $24 \mathrm{~h}$ ) in the DG.

\section{Does Dexefaroxan Treatment Affect the Number of Newborn Cells in the DG?}

To determine whether dexefaroxan treatment increases the number of newborn cells in the DG, rats treated with dexefaroxan or vehicle via osmotic minipumps were injected daily for 7 days with BrdU and were killed 21 or 70 days after the beginning of treatment. The 70-day time point was chosen to study long-term survival because it has been shown previously that the number of BrdU-labeled cells in the gcl remains stable from 1 to 6 months after BrdU administration (Dayer et al, 2003).

All BrdU-positive cells observed at days 21 or 70 were large and round with punctate or uniformly stained nuclei and were principally confined to the gcl in both vehicle and dexefaroxan treated animals (Figure $4 \mathrm{a}$ and $\mathrm{b}$ ). Stereological counts in the gcl showed that the number of BrdU-positive cells in the gcl was $43 \%$ higher $(p<0.05)$ in rats treated for 21 days with dexefaroxan than in vehicle-treated controls (Figure $4 \mathrm{c}$ ). When the duration of treatment was extended to 70 days (Figure 4d), BrdU-positive cells in the dexefaroxan group were again significantly more numerous than in the vehicle group $(57 \%, p<0.05)$. These results show that although there was an increase in the number of new-born cells in the gcl in dexefaroxan-treated animals, there was also considerable attrition over time in both treated and untreated animals (average reductions of 493 and 482 cells, respectively). Although the decrease in the number of BrdU-positive cells over time may be due to dilution of BrdU through successive cell divisions, it is most probably the result of an ongoing cell death process (Dayer et al, 2003).

The difference in the absolute number of BrdU-positive cells in the dexefaroxan treatment group, with respect to vehicle, was the same at days 21 and 70 of treatment (average of +840 and +829 cells, respectively). Given the similar rate of BrdU-positive cell attrition in both groups between 21 and 70 days of treatment (average loss of 493 and 482 cells; see above), these results suggest that dexefaroxan critically influenced the generation or survival of cells newly formed during the first 21 days of treatment, but did not affect the process of cell elimination that occurred later.

To examine this hypothesis, we performed a stereological count of cells labeled with BrdU when chronic dexefaroxan treatment was delayed until 21 days after BrdU adminis- 

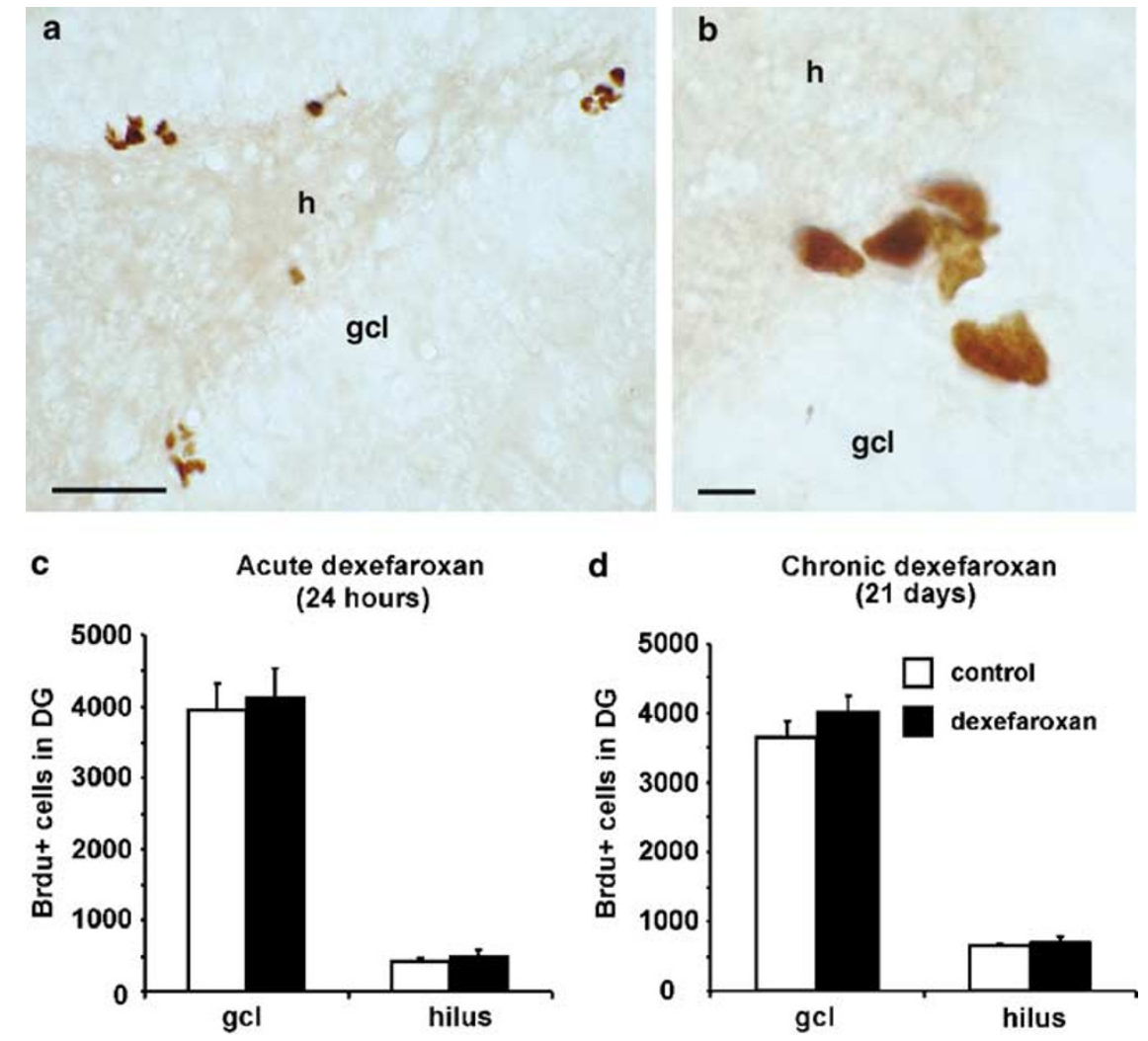

Figure 3 Effect of acute and chronic dexefaroxan treatments on proliferation of dentate gyrus progenitors. Rats received either a single i.p. injection of $\operatorname{BrdU}(50 \mathrm{mg} / \mathrm{kg})$ and four i.p. injections of vehicle $(3 \mathrm{ml} / \mathrm{kg})$ or dexefaroxan $(0.63 \mathrm{mg} / \mathrm{kg})$, or were infused via osmotic minipumps for $2 \mathrm{l}$ days with vehicle or dexefaroxan ( $0.63 \mathrm{mg} / \mathrm{rat} / \mathrm{day})$ and received a single i.p. injection of BrdU $(50 \mathrm{mg} / \mathrm{kg}$ ) on day 20. Rats were killed $24 \mathrm{~h}$ after BrdU injection. (a) A representative photomicrograph of proliferating BrdU-positive cells in the DG, $24 \mathrm{~h}$ after BrdU injection. (b) A progenitor cell cluster at higher magnification. ( $c$ and $d$ ) The number of BrdU-positive cells was the same in dexefaroxan-treated and control rats in both the acute (c) and chronic (d) treatment paradigms. Values are means \pm SEM ( $n=5$ rats per group). Scale bars $=50 \mu \mathrm{m}$ (a) and $5 \mu \mathrm{m}$ (b).

tration and continued to day 70 . When dexefaroxan treatment was delayed to day 21 , the difference between treated and untreated animals at day 70 was no longer observed (Figure 4e), suggesting that dexefaroxan affected cell survival almost exclusively during the first 21 days.

To further examine this hypothesis, we used terminal transfer labeling (TUNEL) to label cells with fragmented chromatin after 21 days of treatment with dexefaroxan or vehicle (Figure 4f). Stereological counts show that dexefaroxan treatment caused a significant decrease (-29\%; $p<0.05)$ in the number of TUNEL-labeled cells at day 21 (Figure 4f), confirming that the alpha2-adrenoceptor antagonist promoted cell survival rather than proliferation.

\section{Effect of Dexefaroxan Treatments on the Differentiation of Newborn Granule Cells}

Finally, we determined whether the BrdU-labeled cells in the DG were neurons or astrocytes, and the effect of dexefaroxan on these two types of neural cells. Double immunolabeling of the BrdU cells was performed with antibodies against the neuronal marker NeuN and the astrocytic marker GFAP (Figure 5), after both 21 and 70 days of chronic treatment with dexefaroxan. Both NeuN/BrdU (Figure $5 \mathrm{a}$ and $\mathrm{b}$ ) and GFAP/BrdU (Figure $5 \mathrm{c}$ and $\mathrm{d}$ ) colabeled cells were detected. The NeuN/BrdU-positive cells largely out-numbered GFAP/BrdU-positive cells at both time points. After 21 days of treatment, $81.3 \pm 4.5 \%$ of BrdU-positive cells in vehicle-treated animals and $84.9 \pm 5.0 \%$ in dexefaroxan-treated animals were NeuNpositive (Figure 5e). GFAP/BrdU-positive astrocytes represented only $14.1 \pm 1.7$ and $11.5 \pm 1.9 \%$ in vehicle- and dexefaroxan-treated groups, respectively (Figure $5 \mathrm{f}$ ). Similar percentages of BrdU-positive neurons and astrocytes were also found after the 70-day treatment protocol. The number of BrdU/NeuN-labeled cells at both time points was significantly higher in dexefaroxan-treated animals than in vehicle-treated controls. There was a significantly greater number of BrdU/NeuN-colabeled cells in dexefaroxantreated animals than in vehicle-treated controls at day 21 $(2359 \pm 92$ and $1570 \pm 117$, respectively; $p<0.05$, Figure 5e) and day $70(2080 \pm 127$ and $1252 \pm 99 ; p<0.05)$. The effect was the same at both time points $(+789$ and +828 cells $)$. Similarly, at day 70 there was a significant difference between the number of GFAP/BrdU-labeled cells in vehicleand dexefaroxan-treated animals (Figure 5f). The large majority of BrdU-positive cells quantified was therefore neurons.

The above results show that dexefaroxan treatment increases the number of newborn granule cells in the DG. To determine whether it also affects their state of differentiation, we evaluated the number of cells expressing 

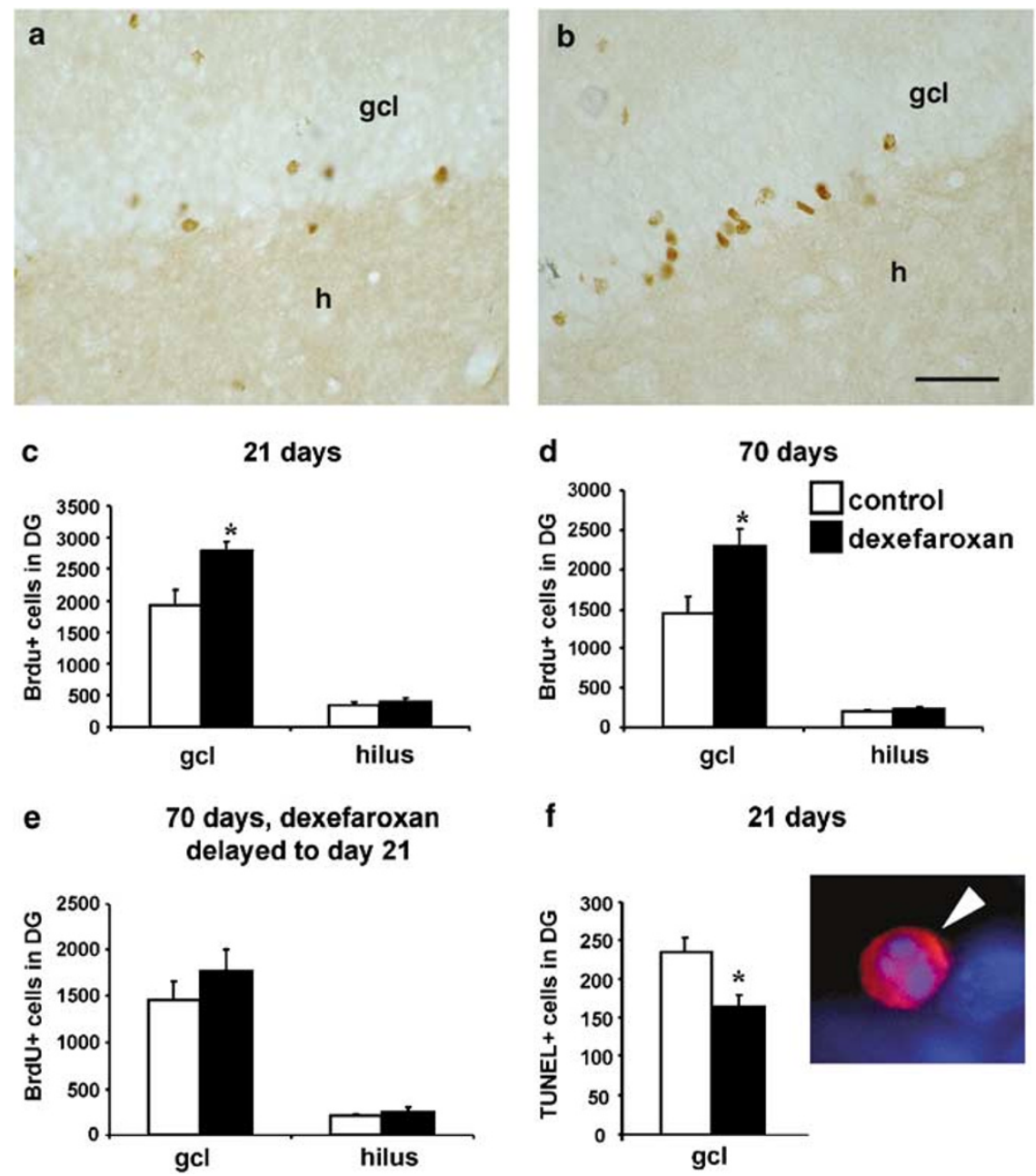

Figure 4 Effect of chronic dexefaroxan treatment on the survival of newly born granule cells. Cells were examined after 7 consecutive daily injections of $\mathrm{BrdU}$ in rats infused with dexefaroxan $(0.63 \mathrm{mg} / \mathrm{rat} /$ day) or vehicle (distilled water) from day 0 to 21 (a-c and f), 0 to 70 (d), and 21 to 70 (e). (a and b) BrdU-positive cells (DAB staining) in the gcl of rats receiving vehicle (a) and dexefaroxan (b) for 21 days. (c and d) The number of BrdU-positive cells was significantly increased in the gcl but not the hilus after 21 (c) and 70 (d) days of dexefaroxan treatment. (e) The effect was not statistically significant if treatment was delayed by 21 days. ( $f$ ) The number of TUNEL-positive cells was lower after a 21 -day treatment with dexefaroxan than with vehicle; note condensed chromatin in TUNEL-positive cells (photo inset, arrowhead). Values are the mean \pm SEM $(n=5)$. *Significantly different from vehicle controls $(p<0.05)$. Scale bar $=50 \mu \mathrm{m}$ (a and $b)$.

PSA-NCAM, a marker of activity-induced synaptic plasticity (Muller et al, 1996) after 21 days of vehicle or dexefaroxan treatment (Figure 6). PSA-NCAM-positive cells were located in the deepest region of the gcl at the interface of the hilus (Figure 6a-d). These cells had the morphological characteristics of granule neurons, with apical dendritic trees expanding into the granular layer (Figure $6 c$ and $d$ ). However, the dendritic arborization was more complex in dexefaroxan-treated animals (Figure 6d) than in vehicletreated controls (Figure $6 \mathrm{c}$ ). This was also seen when doublecortin, a marker for dendritic growth of newly generated neurons (Rao and Shetty, 2004), was immunolabeled in vehicle- (Figure 6e) and dexefaroxan-treated (Figure 6f) animals.

Stereological cell counts showed that dexefaroxan increased the number of PSA-NCAM-positive cells by a mean of $50 \%$ in the sgz of the DG compared to vehicle treatment $(56378 \pm 3723$ vs $37478 \pm 4123$ cells, respectively; $p<0.05)$ (Figure 6g).

\section{Dexefaroxan Treatment Increases BDNF Expression in the DG}

$\mathrm{BDNF}$ is a known proliferation, differentiation, and survival factor for progenitor cells (Katoh-Semba et al, 2002; Lee et al, 2002; Shetty and Turner, 1998) that has been detected in the noradrenergic neurons of the locus coeruleus (Fawcett et al, 1998). We therefore investigated whether the dexefaroxan-induced increase in the survival and differentiation of newborn granule cells was related to a change in BDNF expression in the dorsal hippocampus. In control rats, BDNF immunoreactivity was pronounced in the hilus and CA3 region (Figure 7a). After 21 days of dexefaroxan treatment, BDNF immunoreactivity was markedly enhanced (Figure 7b). The enhancement was still observed after 70 days of treatment (not shown). The increase could already be observed $24 \mathrm{~h}$ after i.p. injection of $0.63 \mathrm{mg} / \mathrm{kg}$ (not shown), indicating that there was a temporal correlation between the treatment and the levels of BDNF in the DG. 

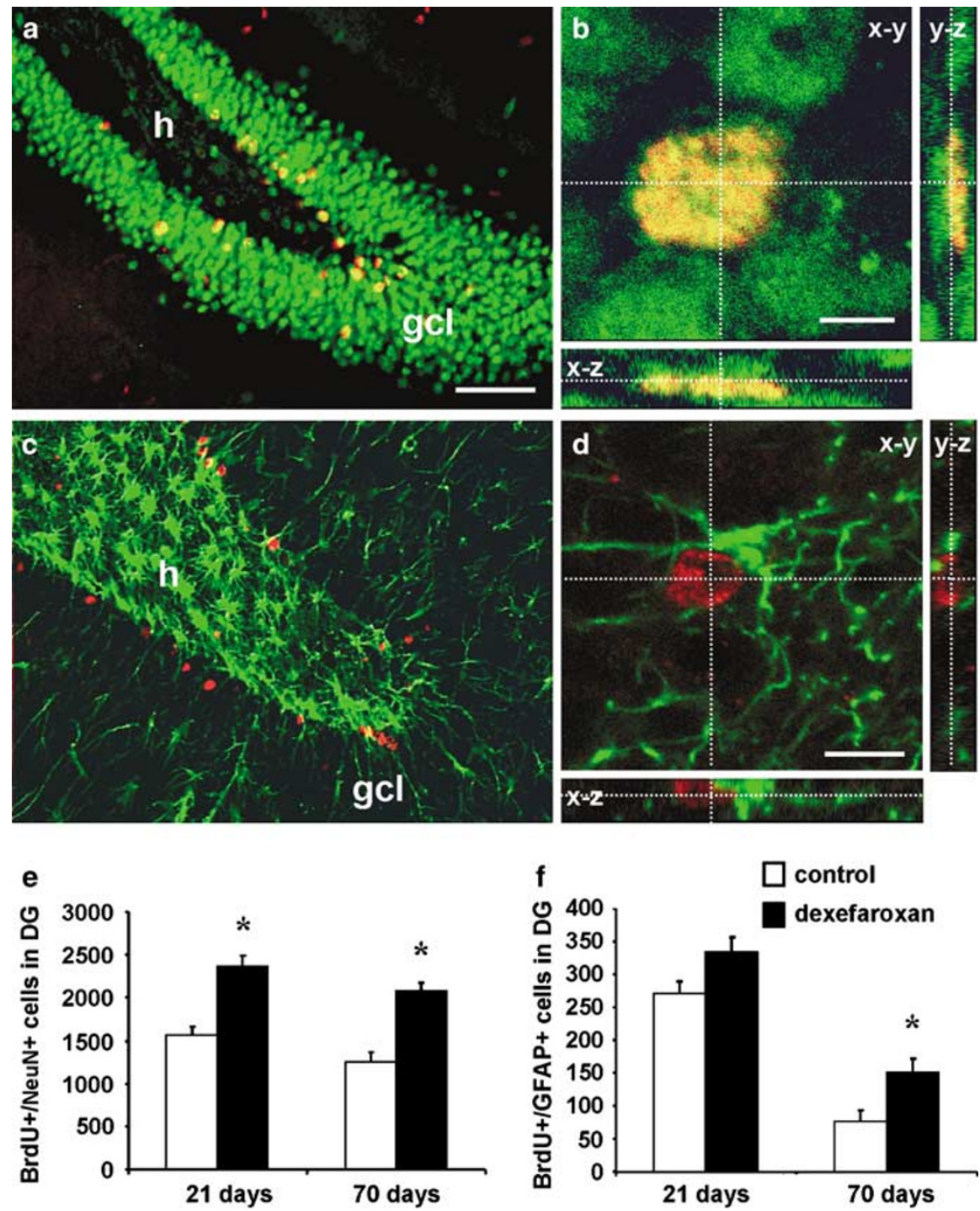

Figure 5 Dexefaroxan increases the number of surviving new neurons without affecting the neuron/glia ratio. (a-d) BrdU/NeuN-positive neurons (a and b) and BrdU/GFAP-positive glial cells (c and d) in coronal sections of the DG after 21 days of treatment with dexefaroxan. Corresponding orthogonal reconstructions of confocal images in $x-y, x-z$, and $y-z$ planes are shown in (b) and (d). (e and f) There were significantly more NeuN/BrdU-positive cells in dexefaroxan-treated animals after both 21 and 70 days of treatment (e) and GFAP/BrdU-positive cells at day 70 ( $f$ ). Values are means \pm SEM ( $n=5$ rats per group). *Significantly different from vehicle controls $(p<0.05)$. Scale bars $=50 \mu \mathrm{m}$ (a and $c), 5 \mu \mathrm{m}(b)$, and $10 \mu \mathrm{m}(\mathrm{d})$.

The increase in BDNF immunoreactivity was particularly evident in the gcl, the hilus, and the stratum radiatum of CA3, but not in the CA1 region (Figure $7 \mathrm{~b}$ ). Quantitative analysis of BDNF immunostaining after 21 days of treatment is shown in Figure 7e. A significant increase in BDNF immunostaining was observed in the hilus $(276 \%)$, in the gcl $(181 \%)$, in the cell layer of the CA3 $(156 \%)$, and in the stratum radiatum of CA3 (143\%) of dexefaroxantreated animals compared to controls (Figure 7e). No differences in BDNF staining after treatment were observed in other regions of the brain such as the CAl of the hippocampus, frontal cortex, or temporal cortex (data not shown), although this could be due to levels of BDNF in these regions undetectable by our method. Several cells in the gcl were intensely stained in their cytoplasm, while those in the sgz were only weakly stained (Figure $7 \mathrm{~d}$ ). Furthermore, enhanced BDNF immunostaining was observed in the mossy fibers in the hilar region and the CA3 (Figure $7 b, d$ ).

\section{DISCUSSION}

In the present study, neurogenesis in the adult rat dorsal hippocampus in vivo was enhanced by chronic systemic treatment with the selective alpha2-adrenoceptor antagonist dexefaroxan. The treatment increased both the long-term survival of new granule cells in the DG and the extent and complexity of their neuritic arborization. Dexefaroxan treatment also increased the expression of BDNF in the hippocampal neuropil and in granule cell neurons, suggesting that it could play a role in the effects of the alpha2adrenoceptor antagonist on neurogenesis in this brain structure.

\section{Dexefaroxan Acts at a Critical Period for Cell Survival}

Neurogenesis is the net outcome of cell proliferation and cell death. Chronic dexefaroxan treatment was found to 

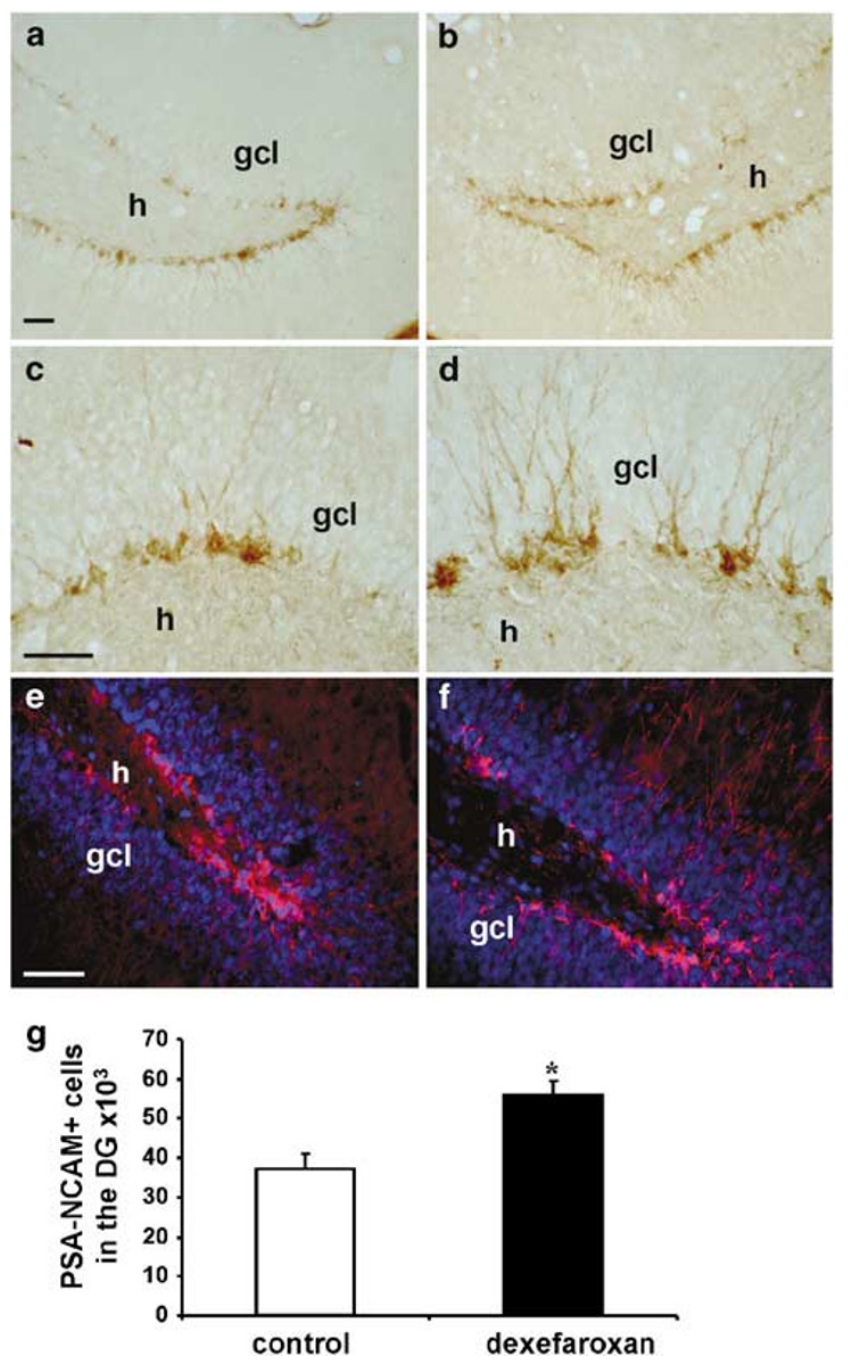

Figure 6 Dexefaroxan treatment enhances neural plasticity in the DG. (a-d) Representative light microscopic images of PSA-NCAM-immunoreactive cells in the DG of control (a and $c$ ) and dexefaroxan-treated (b and d) rats after 21 days of treatment. Note the higher level of PSA-NCAM expression (b) and the more complex dendritic arborization (d) in dexefaroxan-treated animals. ( $e$ and $f$ ) Doublecortin immunoreactivity (red) also increased in dexefaroxan-treated rats ( $f$ ) compared to controls (e) (nuclei stained with Hoechst 33342, blue). (g) The number of PSANCAM-positive cells in dexefaroxan-treated rats also increased compared to vehicle controls. *Significantly greater than controls $(p<0.05)$. Scale bars $=15 \mu \mathrm{m}$ ( $\mathrm{a}$ and b), $30 \mu \mathrm{m}$ ( $c$ and d), and $50 \mu \mathrm{m}$ (e and f).

Figure 7 Dexefaroxan enhances BDNF expression in the DG. (a and b) BDNF immunoreactivity (red) is greater in the hilus and CA3 region of dexefaroxan-treated rats (b) than in controls (a) after $2 \mathrm{I}$ days of treatment. (c and d) Higher magnification shows a homogeneous pattern of immunoreactivity in the control DG (c) and intensely stained granule cells in dexefaroxan-treated animals (d). Nuclei stained with Hoechst 33342 (blue) in (c) and (d). (e) Quantitative analysis of BDNF immunostaining after 21 days of treatment shows an average three-fold increase in BDNF levels in the gcl and CA3 area of dexefaroxan-treated rats compared to vehicle controls. The greatest increase was observed in the hilus. *Significantly greater than controls $(p<0.05)$. Scale bars $=100 \mu \mathrm{m}$ (a and b) and $10 \mu \mathrm{m}$ (c and d). increase net neurogenesis by promoting long-term cell survival, rather than modifying cell proliferation. Under our experimental conditions, many of the newborn cells in the DG were eliminated within the first 21 days after their generation. This was consistent with a previous study showing a $50 \%$ loss of BrdU positive cells between the first and fourth week after BrdU-labeling, and that the new
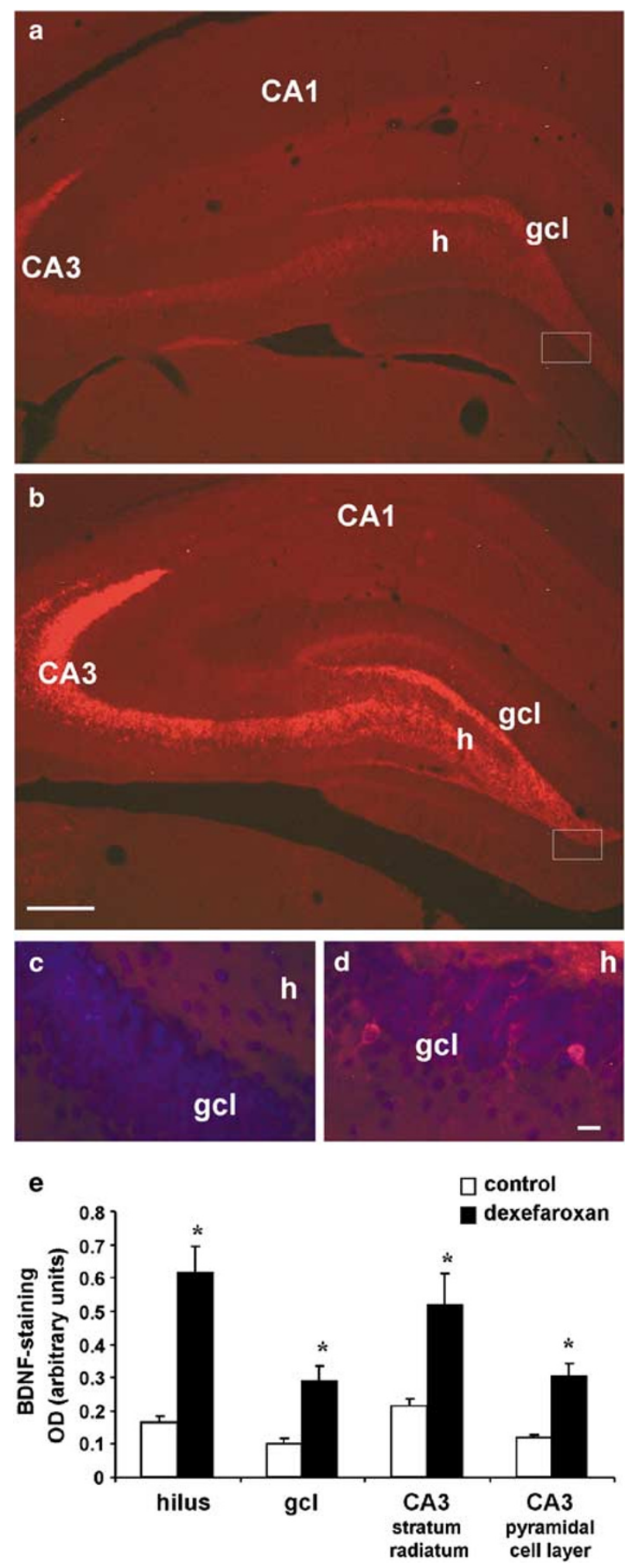
granule cells that survived persisted for several more months (Dayer et al, 2003). The first 21 days following the birth of the new cells were critical for the observation of a dexefaroxan-induced increase in cell survival. Indeed, when dexefaroxan treatment was delayed for 21 days after BrdU administration, we observed no significant effect on cell survival, reinforcing the notion of a critical window for drug action. What happens in the 7-14 day period following the birth of a new cell must now be determined more precisely. The TUNEL findings indicate that dexefaroxan was protective against apoptotic cell death and could affect new cells during this early phase of cell sensitivity.

\section{Dexefaroxan may also Enhance Neuronal Plasticity}

In addition to increasing the number of new neurons, dexefaroxan apparently enhanced their differentiation, increasing quite spectacularly the extent and the complexity of their dendritic arborization visualized with an antibody against PSA-NCAM, a putative marker of activity-induced plasticity in the hippocampus (Cremer et al, 2000; Muller et al, 1996). PSA-NCAM is associated with granule neurons and mossy fiber boutons in the adult hippocampus, and is thought to participate in the formation and remodeling of synapses between granule neurons and CA3 pyramidal neurons (Seki and Arai, 1999). The expression of doublecortin, a marker of dendritic growth in newly generated neurons (Rao and Shetty, 2004), also increased in the hippocampus in a pattern similar to that of PSA-NCAM. In both cases, the dendritic arborizations of the granule cell neurons appeared to be more elaborate. Although this may be due to a better visualization of the dendritic arbors in cells expressing higher levels of the markers, these results suggest that dexefaroxan may have an effect on dendritic morphology. It may be hypothesized that the effect on morphology contributes to the reported long-term enhancement of sensory-evoked potentials in the DG (Harley, 1991).

The effect of dexefaroxan on the survival of newly formed granule cells and on PSA-NCAM expression may be indicative of the functional integration of these cells into hippocampal neuronal circuits. The time period during which dexefaroxan affected the survival of newborn granule cells coincided with the period in which these cells can extend axons into the CA3 region (Hastings and Gould, 1999). In a neurotrophin-dependent model of hippocampal progenitor differentiation, granule cell survival appears to be dependent on their integration and subsequent synaptic activity (Castren, 2004).

In apparent contradiction with our study, it was previously reported that noradrenaline depletion reduced hippocampal neurogenesis by decreasing proliferation, without affecting cell survival or differentiation (Kulkarni et al, 2002). These findings together with our own indicate that hippocampal neurogenesis is sensitive to the state of activation of the locus coeruleus-noradrenergic system, and suggest that the degree of noradrenergic tonus might somehow determine the relative participation of receptor subtypes and their different signaling pathways at different stages of the neurogenetic process. We cannot rule out a direct effect of the alpha2-adrenoceptor antagonist dexefaroxan on neurogenesis and the use of other specific adrenoceptor ligands to further identify that the receptor subtype candidates for receptor mediation of these noradrenergic effects would be useful to better understand the mechanisms involved. However, the results obtained with dexefaroxan in the olfactory bulb (Bauer et al, 2003) are similar. Reminiscent of what we find in the hippocampus, the survival-promoting effect of dexefaroxan was concluded by Bauer et al (2003) to result from a reduction in apoptotic cell death and not from a modification of progenitor proliferation. The remarkable similarities between the effects of dexefaroxan in these two in vivo studies suggest that neurogenesis in these otherwise disparate parts of the brain is regulated by common noradrenergic mechanisms.

\section{What Mechanism Underlies the Effects of Dexefaroxan on the Survival and Differentiation of New Neurons in the Hippocampus?}

The hippocampus is extensively innervated by noradrenergic fibers projecting exclusively from the locus coerulus (Loy et al, 1980), and all major classes of adrenoceptors are found in this structure (Nicholas et al, 1996). In the present study, NET-positive fibers were abundant at the interface between the hilus and gcl, and in contact with both proliferating cells (PCNA positive) and immature differentiating neurons (PSA-NCAM positive).

Presynaptic alpha2-adrenoceptors are most likely responsible for dexefaroxan-induced noradrenaline release in the hippocampus (Arima et al, 1998; Starke, 2001; van Veldhuizen et al, 1994). Postsynaptic alpha2-adrenoceptors have been reported to enhance apoptosis in a cell culture system when activated and to delay apoptosis when inhibited (Wang and Limbird, 1997), and may therefore be involved in the effects of dexefaroxan on neuronal survival. Other adrenoceptors may also play a role, however. Postsynaptic alpha1-adrenoceptors were also reported to have antiapoptotic activity in some cellular systems (Popovik and Haynes, 2000). The role of postsynaptic beta-adrenoceptors has not been evaluated. The individual contributions and possible interactions of all these receptors on neurogenesis remain subject to further investigation. A receptor-independent effect of noradrenaline that can act as an antioxidant might also promote neuronal survival (Traver et al, 2005; Troadec et al, 2001).

Our study also points to a role of BDNF in the noradrenergic regulation of neurogenesis. BDNF is present in locus coeruleus-noradrenergic projections (Aloyz et al, 1999) and undergoes anterograde transport to terminal fibers. In our study, BDNF expression was massively upregulated from the beginning of dexefaroxan treatment, in the afferent noradrenergic fibers from the locus coeruleus, in all neurons in the gcl, and in their projections, the mossy fibers, to CA3. In vitro, BDNF has been shown to enhance neurogenesis by increasing both the proliferation of neural stem cells and their survival (Katoh-Semba et al, 2002; Lee et al, 2002; Shetty and Turner, 1998). Its role in dexefaroxan-induced survival and differentiation of new granule cells in the adult hippocampus thus warrants further study, notably with respect to the relationship between BDNF expression and neuronal activity. A strong upregulation of BDNF expression in the hippocampus, comparable to what we have observed following dexefaroxan treatment, has been associated with seizures (Binder 
et al, 2001), a situation in which neurogenesis is induced (Parent et al, 1997). Neurogenesis in response to increased neuronal activity has been reported in a number of models (Bai et al, 2003; Derrick et al, 2000), and BDNF is reported to increase neurotransmission in the hippocampus ( $\mathrm{Lu}$, 2004). Most interestingly, unilateral BDNF infusion in the DG was reported to induce neurogenesis in the contralateral hemisphere, a result which may be explained by BDNFdependent enhancement of transmission by hippocampal neurons such as the pyramidal cells with commissural projections (Scharfman et al, 2005). Alternatively, dexefaroxan treatment could increase BDNF levels by increasing neuronal activity. Alpha2-autoreceptor blockade, which leads to increased activation of the noradrenergic neurons in the locus coeruleus, may result in an increase in the activity-dependent synthesis and anterograde transport of BDNF from the locus coeruleus to forebrain target regions (Fawcett et al, 1998).

\section{The Noradrenergic System as a Target for Therapeutic Manipulation of Adult Neurogenesis in the Hippocampus}

In animal studies, hippocampal neurogenesis has been postulated to play a role in learning and memory (Gould et $a l, 1999 \mathrm{~b})$. Impaired performance on hippocampusdependent learning tasks was observed when neurogenesis was reduced in the hippocampus and was restored when neurogenesis resumed (Shors et al, 2001, 2002). Conversely, performance of such learning tasks increased neurogenesis and enhanced the survival of new granule cells in the hippocampus (Gould et al, 1999a). This occurred on a time scale suggesting that newly formed cells become functional around 1-2 weeks after their generation, as they integrate into the gcl and make synaptic contact with targets in the CA3 area (Hastings and Gould, 1999). These new cells appear to facilitate synaptic plasticity, since the induction of associative long-term potentiation in these cells is more rapid than in mature neurons (Schmidt-Hieber et al, 2004). Enhancement of the survival and plasticity of newborn neurons by pharmacological activation of the locus coeruleus-noradrenergic system may therefore provide a way to facilitate certain types of hippocampal learning and memory. Dexefaroxan has indeed been shown to improve the performance of rodents in tests of both short- and longterm memory, and to ameliorate the performance of old rats on the Morris water maze and passive avoidance tasks to the level of young adult animals (Chopin et al, 2002). Although the increased survival of newborn neurons may result in the functional improvement reported, acute effects of BDNF on synaptic activity in the hippocampus cannot be excluded.

Can adult neurogenesis be used for treating neurodegenerative diseases? Hippocampal neurogenesis was shown recently to be increased in Alzheimer's disease, possibly as a compensatory attempt to replace lost neurons (Jin et al, 2004). Although neurogenesis is reduced with normal aging, the aged brain may retain a capacity to upregulate neurogenesis in response to some pathological or pharmacological challenges (Cameron and McKay, 1999; Seki and Arai, 1995). Enhancing new neuron survival, facilitating structural plasticity, and stimulating the expression of neurotrophins in the hippocampus may constitute poten- tially effective compensatory strategies in neurodegenerative conditions like Alzheimer's disease, in which hippocampal function is impaired (Tatebayashi et al, 2003). Dexefaroxan had such effects in our study, and may therefore be of therapeutic interest for the treatment of these disorders.

\section{ACKNOWLEDGEMENTS}

Pamela Rizk was financed by the Association France Alzheimer (www.francealzheimer.org). We gratefully acknowledge the excellent technical assistance of Jérôme Floutard (CRPF) in performing the microdialysis experiments and HPLC measurements of noradrenaline.

\section{REFERENCES}

Aloyz R, Fawcett JP, Kaplan DR, Murphy RA, Miller FD (1999). Activity-dependent activation of TrkB neurotrophin receptors in the adult CNS. Learn Mem 6: 216-231.

Arima J, Kubo C, Ishibashi H, Akaike N (1998). Alpha2adrenoceptor-mediated potassium currents in acutely dissociated rat locus coeruleus neurones. J Physiol 508(Part 1): 57-66.

Bai F, Bergeron M, Nelson DL (2003). Chronic AMPA receptor potentiator (LY451646) treatment increases cell proliferation in adult rat hippocampus. Neuropharmacology 44: 1013-1021.

Bauer S, Moyse E, Jourdan F, Colpaert F, Martel JC, Marien M (2003). Effects of the alpha 2-adrenoreceptor antagonist dexefaroxan on neurogenesis in the olfactory bulb of the adult rat in vivo: selective protection against neuronal death. Neuroscience 117: 281-291.

Binder DK, Croll SD, Gall CM, Scharfman HE (2001). BDNF and epilepsy: too much of a good thing? Trends Neurosci 24: 47-53.

Cameron HA, McKay RD (1999). Restoring production of hippocampal neurons in old age. Nat Neurosci 2: 894-897.

Cameron HA, McKay RD (2001). Adult neurogenesis produces a large pool of new granule cells in the dentate gyrus. J Comp Neurol 435: 406-417.

Cameron HA, Woolley CS, McEwen BS, Gould E (1993). Differentiation of newly born neurons and glia in the dentate gyrus of the adult rat. Neuroscience 56: 337-344.

Castren E (2004). Neurotrophic effects of antidepressant drugs. Curr Opin Pharmacol 4: 58-64.

Chopin P, Colpaert FC, Marien M (2002). Effects of acute and subchronic administration of dexefaroxan, an alpha(2)-adrenoceptor antagonist, on memory performance in young adult and aged rodents. J Pharmacol Exp Ther 301: 187-196.

Cremer H, Chazal G, Lledo PM, Rougon G, Montaron MF, Mayo W et al (2000). PSA-NCAM: an important regulator of hippocampal plasticity. Int J Dev Neurosci 18: 213-220.

Dayer AG, Ford AA, Cleaver KM, Yassaee M, Cameron HA (2003). Short-term and long-term survival of new neurons in the rat dentate gyrus. J Comp Neurol 460: 563-572.

Derrick BE, York AD, Martinez Jr JL (2000). Increased granule cell neurogenesis in the adult dentate gyrus following mossy fiber stimulation sufficient to induce long-term potentiation. Brain Res 857: 300-307.

Doetsch F, Alvarez-Buylla A (1996). Network of tangential pathways for neuronal migration in adult mammalian brain. Proc Nat Acad Sci USA 93: 14895-14900.

Duman RS, Malberg J, Nakagawa S (2001a). Regulation of adult neurogenesis by psychotropic drugs and stress. J Pharmacol Exp Ther 299: 401-407.

Duman RS, Nakagawa S, Malberg J (2001b). Regulation of adult neurogenesis by antidepressant treatment. Neuropsychopharmacology 25: 836-844. 
Eriksson PS, Perfilieva E, Bjork-Eriksson T, Alborn AM, Nordborg C, Peterson DA et al (1998). Neurogenesis in the adult human hippocampus. Nat Med 4: 1313-1317.

Fawcett JP, Bamji SX, Causing CG, Aloyz R, Ase AR, Reader TA et al (1998). Functional evidence that BDNF is an anterograde neuronal trophic factor in the CNS. J Neurosci 18: 2808-2821.

Gould E, Beylin A, Tanapat P, Reeves A, Shors TJ (1999a). Learning enhances adult neurogenesis in the hippocampal formation. Nat Neurosci 2: 260-265.

Gould E, Tanapat P, Hastings NB, Shors TJ (1999b). Neurogenesis in adulthood: a possible role in learning. Trends Cogn Sci 3: $186-192$.

Harley C (1991). Noradrenergic and locus coeruleus modulation of the perforant path-evoked potential in rat dentate gyrus supports a role for the locus coeruleus in attentional and memorial processes. Prog Brain Res 88: 307-321.

Hastings NB, Gould E (1999). Rapid extension of axons into the CA3 region by adult-generated granule cells. J Comp Neurol 413: $146-154$

Howard V, Reid S, Baddeley A, Boyde A (1985). Unbiased estimation of particle density in the tandem scanning reflected light microscope. J Microsc 138(Part 2): 203-212.

Jin K, Peel AL, Mao XO, Xie L, Cottrell BA, Henshall DC et al (2004). Increased hippocampal neurogenesis in Alzheimer's disease. Proc Natl Acad Sci USA 101: 343-347.

Katoh-Semba R, Asano T, Ueda H, Morishita R, Takeuchi IK, Inaguma $Y$ et al (2002). Riluzole enhances expression of brainderived neurotrophic factor with consequent proliferation of granule precursor cells in the rat hippocampus. FASEB $J$ 16: $1328-1330$.

Kuhn HG, Dickinson-Anson H, Gage FH (1996). Neurogenesis in the dentate gyrus of the adult rat: age-related decrease of neuronal progenitor proliferation. J Neurosci 16: 2027-2033.

Kulkarni VA, Jha S, Vaidya VA (2002). Depletion of norepinephrine decreases the proliferation, but does not influence the survival and differentiation, of granule cell progenitors in the adult rat hippocampus. Eur J Neurosci 16: 2008-2012.

Lee J, Duan W, Mattson MP (2002). Evidence that brain-derived neurotrophic factor is required for basal neurogenesis and mediates, in part, the enhancement of neurogenesis by dietary restriction in the hippocampus of adult mice. J Neurochem 82: 1367-1375.

Lois C, Alvarez-Buylla A (1994). Long-distance neuronal migration in the adult mammalian brain. Science 264: 1145-1148.

Loy R, Koziell DA, Lindsey JD, Moore RY (1980). Noradrenergic innervation of the adult rat hippocampal formation. J Comp Neurol 189: 699-710.

$\mathrm{Lu} \mathrm{B} \mathrm{(2004).} \mathrm{Acute} \mathrm{and} \mathrm{long-term} \mathrm{synaptic} \mathrm{modulation} \mathrm{by}$ neurotrophins. Prog Brain Res 146: 137-150.

Malberg JE, Eisch AJ, Nestler EJ, Duman RS (2000). Chronic antidepressant treatment increases neurogenesis in adult rat hippocampus. J Neurosci 20: 9104-9110.

Muller D, Wang C, Skibo G, Toni N, Cremer H, Calaora V et al (1996). PSA-NCAM is required for activity-induced synaptic plasticity. Neuron 17: 413-422.

NCR (National research council) (1996). Guide for the Care and Use of Laboratory Animals. National Academic Press: Washington, DC.

Nicholas AP, Hokfelt T, Pieribone VA (1996). The distribution and significance of CNS adrenoceptors examined with in situ hybridization. Trends Pharmacol Sci 17: 245-255.

Parent JM, Yu TW, Leibowitz RT, Geschwind DH, Sloviter RS, Lowenstein DH (1997). Dentate granule cell neurogenesis is increased by seizures and contributes to aberrant network reorganization in the adult rat hippocampus. J Neurosci 17: $3727-3738$.
Paxinos G, Watson C (1986). The Rat Brain in stereotaxic Coordinates, 2nd edn. Academic Press: Sydney.

Popovik E, Haynes LW (2000). Survival and mitogenesis of neuroepithelial cells are influenced by noradrenergic but not cholinergic innervation in cultured embryonic rat neopallium. Brain Res 853: 227-235.

Rao MS, Shetty AK (2004). Efficacy of doublecortin as a marker to analyse the absolute number and dendritic growth of newly generated neurons in the adult dentate gyrus. Eur J Neurosci 19: 234-246.

Scharfman H, Goodman J, Macleod A, Phani S, Antonelli C, Croll S (2005). Increased neurogenesis and the ectopic granule cells after intrahippocampal BDNF infusion in adult rats. Exp Neurol 192: 348-356.

Schmidt-Hieber C, Jonas P, Bischofberger J (2004). Enhanced synaptic plasticity in newly generated granule cells of the adult hippocampus. Nature 429: 184-187.

Seki T, Arai Y (1995). Age-related production of new granule cells in the adult dentate gyrus. Neuroreport 6: 2479-2482.

Seki T, Arai Y (1999). Different polysialic acid-neural cell adhesion molecule expression patterns in distinct types of mossy fiber boutons in the adult hippocampus. J Comp Neurol 410: 115-125.

Shetty AK, Turner DA (1998). In vitro survival and differentiation of neurons derived from epidermal growth factor-responsive postnatal hippocampal stem cells: inducing effects of brainderived neurotrophic factor. J Neurobiol 35: 395-425.

Shors TJ, Miesegaes G, Beylin A, Zhao M, Rydel T, Gould E (2001). Neurogenesis in the adult is involved in the formation of trace memories. Nature 410: 372-376.

Shors TJ, Townsend DA, Zhao M, Kozorovitskiy Y, Gould E (2002). Neurogenesis may relate to some but not all types of hippocampal-dependent learning. Hippocampus 12: 578-584.

Starke K (2001). Presynaptic autoreceptors in the third decade: focus on alpha2-adrenoceptors. J Neurochem 78: 685-693.

Tatebayashi Y, Lee MH, Li L, Iqbal K, Grundke-Iqbal I (2003). The dentate gyrus neurogenesis: a therapeutic target for Alzheimer's disease. Acta Neuropathol (Berlin) 105: 225-232.

Tellez S, Colpaert F, Marien M (1999). Alpha2-adrenoceptor modulation of cortical acetylcholine release in vivo. Neuroscience 89: 1041-1050.

Tonchev AB, Yamashima T, Zhao L, Okano HJ, Okano H (2003). Proliferation of neural and neuronal progenitors after global brain ischemia in young adult macaque monkeys. Mol Cell Neurosci 23: 292-301.

Traver S, Salthun-Lassalle B, Marien M, Hirsch EC, Colpaert F, Michel PP (2005). The neurotransmitter noradrenaline rescues septal cholinergic neurons in culture from degeneration caused by low-level oxidative stress. Mol Pharmacol 67: 1882-1891.

Troadec JD, Marien M, Darios F, Hartmann A, Ruberg M, Colpaert $\mathrm{F}$ et al (2001). Noradrenaline provides long-term protection to dopaminergic neurons by reducing oxidative stress. J Neurochem 79: $200-210$

van Veldhuizen MJ, Feenstra MG, Boer GJ (1994). Regional differences in the in vivo regulation of the extracellular levels of noradrenaline and its metabolites in rat brain. Brain Res 635: 238-248.

Wang RX, Limbird LE (1997). Distribution of mRNA encoding three alpha 2-adrenergic receptor subtypes in the developing mouse embryo suggests a role for the alpha $2 \mathrm{~A}$ subtype in apoptosis. Mol Pharmacol 52: 1071-1080.

Yoshitake T, Fujino K, Kehr J, Ishida J, Nohta H, Yamaguchi M (2003). Simultaneous determination of norepinephrine, serotonin, and 5-hydroxyindole-3-acetic acid in microdialysis samples from rat brain by microbore column liquid chromatography with fluorescence detection following derivatization with benzylamine. Anal Biochem 312: 125-133. 